\title{
Kesesuaian aspek kebahasaan BSE bahasa Indonesia SMP terhadap standar isi
}

\author{
Muhammad Fahmi ${ }^{1}$, Dwi Rohman Saleh ${ }^{2}$ \\ 1,2)Universitas PGRI Madiun, Jl. Setibudi No. 85 Madiun, Indonesia \\ e-mail: ${ }^{1}$ barangsiapa@gmail.com; ${ }^{2}$ rohmansolehdwi@yahoo.com
}

\begin{abstract}
Abstrak
Terobosan luar biasa yang dilakukan pemerintah dalam penerapan $\mathrm{K}-13$ ini adalah Buku Sekolah Elektronik (BSE). BSE pun diperbolehkan untuk dicetak dan diperbanyak tanpa membayar royalti ke pemerintah. BSE diberikan secara masif. Semua sekolah bisa mengaksesnya. Penelitian bertujuan untuk melihat sejauh mana kekurangan, terutama pada aspek kebahasaan, dalam BSE Bahasa Indonesia kelas VII Kurikulum 2013. Terdapat 3 aspek kebahasaan yang dinilai dari sebuah buku teks, yaitu (1) aspek kesesesuaian dengan tingkat perkembangan peserta didik; (2) komunikatif; dan (3) keruntutan dan kepaduan paragraf. Pada aspek kesesuaian dengan tingkat perkembangan peserta didik hasil penelitian memperlihatkan bahwa di BSE Bahasa Indonesia kelas VII ditemukan 30 kata yang tidak sesuai dengan perkembangan intelektual peserta didik. Peserta didik tidak mampu memahami katakata tersebut adalah karena mereka tidak biasa atau tidak pernah melihat atau mendengar kata-kata tersebut. Pada penilaian aspek komunikatif di buku ini ditemukan: (1) permasalahan tentang makna ganda (tidak jelas) kalimat; (2) kesalahan tanda baca; (3) dan inkonsistensi. Pada penilaian aspek keruntutan dan kesatuan gagasan ditemukan masalah: (1) tidak adanya hubungan antara subbab dengan subbab sebelum dan sesudahnya; (2) pengulangan kalimat yang tidak perlu; (3) dan hubungan antarkalimat yang membingungkan.
\end{abstract}

Kata kunci: Kesesuaian Bahasa; BSE Bahasa Indonesia kelas VII; Standar Isi; Kurikulum 2013

\section{Language aspects suitability on Electronic School Book (BSE) of Indonesian subject towards content standard}

\begin{abstract}
The government's outstanding breakthrough in implementing the 2013 Curriculum is the Electronic School Book (BSE). BSE is allowed to be printed and reproduced without paying royalties to the government. BSE is given freely and massively. All schools can access it. Therefore, the research is conducted to see the extent of deficiency, especially for language aspects, in BSE of Indonesian subject for the seventh grade of Junior High School based on the 2013 Curriculum.There are 3 aspects of language that are assessed from a textbook, namely (1) the aspect of suitability with the level of development of students; (2) communicative aspect; And (3) the coherence and cohesiveness of paragraphs. In the aspect of suitability with the level of development of students, the findings show that BSE of Indonesian subject for the seventh grade of Junior High School find 30 words not matching with the intellectual development of students. The students are not able to understand these words because the words are unusual or never seen or heard before. Viewed from the communicative aspects of this book, it is found that there are: (1) the problems of the double meaning (unclear and ambiguous) sentence; (2) punctuation errors; (3) and inconsistencies. Thus, some problems in the aspect of the coherence
\end{abstract}


and cohesiveness of paragraphs considered to be the problems are that: (1) there is no relationship between the sections with the sub-section; (2) repetition on the unnecessary sentences; (3) and the confusing relationship among sentences.

Keywords: language conformity; BSE bahasa Indonesia class VII; standar isi; curriculum 2013

\section{Pendahuluan}

Penggunaan buku teks pelajaran bahasa Indonesia yang belum diketahui asalusul dan diragukan keabsahannya tidak terjadi. Sebab selama ini buku teks pelajaran menjadi pegangan vital untuk siswa dan guru (Sugiantomas, 2017). Terobosan luar biasa yang dilakukan pemerintah dalam penerapan K-13 ini adalah Buku Sekolah Elektronik (BSE). BSE adalah buku-buku teks sekolah dalam bentuk softcopy atau dikenal dengan istilah e-book yang diterbitkan oleh Kemendikbud. BSE dapat diunduh dalam website milik Kemendikbud secara gratis. Kehadiran BSE sangat membantu bagi sekolah karena pemerintah sudah memberikan patokan buku yang digunakan sehingga sekolah tidak perlu kesulitan mencari rujukan buku. Walaupun tetap saja ada kesulitan dalam distribusinya karena tidak semua daerah memiliki akses internet yang memadai untuk mengunduh buku-buku tersebut. Akan tetapi, akses internet bukanlah domain utama dari Kemendikbud. Usaha Kemendikbud dalam menghadirkan BSE sangatlah inovatif dan layak diapresiasi.

Dengan adanya BSE maka semua sekolah memiliki "kiblat" buku rujukan K-13 mereka. Semua sekolah yang menerapkan K-13 memiliki dan menggunakan buku yang sama. Hal ini tentu akan membantu pemerintah dalam memberikan penerjemahan yang sama berkaitan dengan K-13 kepada semua siswa di Indonesia. Anggapan bahwa BSE pasti sesuai dengan apa yang diinginkan pemerintah pun adalah tidak salah karena penerbit BSE adalah pemerintah. Akan tetapi, bagaimana jika tidak? Bagaimana jika ternyata BSE tidak mencerminkan apa yang diinginkan pemerintah sesuai dengan aturan yang berlaku? Apabila BSE ternyata memiliki kekurangan sebagai buku ajar bukankah akan menjadi kesalahan besar mengingat pengguna BSE adalah sekolah-sekolah di seluruh Indonesia.

Pertanyaan-pertanyaan di atas mengulik peneliti untuk melihat lebih dalam tentang buku BSE. Sebuah SMP di Magetan, tepatnya SMP 1 Plaosan, peneliti survey untuk mendapatkan data awal dari pertanyaan-pertanyaan kecil tersebut. SMP 1 Plaosan dipilih karena SMP ini secara konsisten telah menerapkan K-13 sejak awal diterbitkannya K-13 sampai penelitian ini dilakukan. Peneliti memilih pelajaran Bahasa Indonesia kelas VII sebagai subjek mata pelajaran. Salah satu guru Bahasa Indonesia SMP 1 Plaosan menjadi narasumber dari wawancara pra penelitian (wawancara bisa dilihat di lampiran). Dari hasil wawancara tersebut peneliti mendapatkan data bahwa: (a) materi dalam buku kurang lengkap sehingga guru harus mencari dari sumber yang lain; (b) penggunaan bahasa dalam buku terkadang sulit untuk dipahami siswa, bahkan guru pun kesulitan juga.

Guna mengatur sistem pendidikan nasional di jalur yang diinginkan, pemerintah memiliki sebuah standar nasional pendidikan yang terdiri atas standar isi, proses, kompetensi lulusan, tenaga kependidikan, sarana dan prasarana, pengelolaan, pembiayaan, dan penilaian pendidikan yang harus ditingkatkan secara berencana dan berkala (pasal 25 ayat (1) UU No. 20 tahun 2003 tentang sistem pendidikan nasional). Pada tahun 2016, berdasarkan standar isi pendidikan nasional, pemerintah 
mengeluarkan peraturan tentang buku yang digunakan oleh satuan pendidikan. Pemerintah melalui Peraturan Menteri Pendidikan dan Kebudayaan No. 8 tahun 2016 menegaskan tentang unsur-unsur yang harus dimiliki sebuah buku teks, yaitu memiliki bagian awal, bagian isi, dan bagian akhir buku. Bagian isi yang dimaksud dalam Permendikbud tersebut adalah buku teks pelajaran wajib memenuhi aspek materi, aspek kebahasaan, aspek penyajian, dan aspek kegrafikaan.

Berdasarkan wawancara pra penelitian, maka terlihat bahwa guru sebagai pengguna langsung merasa masih ada kekurangan dalam aspek kebahasaandi buku Bahasa Indonesia kelas VII Kurikulum 2013. Adanya kekurangan ini membuka kemungkinan terjadi kekurangan di aspek lainnya. Kekurangan-kekurangan yang mungkin timbul tersebut adalah subjek yang sangat menarik untuk diteliti lebih dalam. Tujuan dari penelitian ini adalah mengidentifikasi dan menganalisis kesesuaian komponen kebahasaaan dalam buku teks dengan aspek perkembangan peserta didik, aspek komunikatif, dan aspek keruntutuan dan kesatuan gagasan.

\section{Metode Penelitian}

Penelitian inti dilakukan di SMPN 1 Plaosan Magetan. SMPN 1 Plaosan dipilih sebagai tempat penelitian karena di sekolah tersebut telah menjalankan K-13 sejak awal atau sejak pemerintah mengeluarkan peraturan tentang penerapan $\mathrm{K}$ 13.Penelitian ini dilakukan selama bulan April 2017 sampai dengan Agustus 2017.Adapun jenis pendekatan penelitian ini adalah simak catat (content analysis).Analisis ini dipilih karena sesuai dengan jenis datanya yaitu berupa pendapat pemakai isi dari sebuah buku teks Bahasa Indonesia Kelas VII dengan pedoman penilaian buku yang telah dikeluarkan oleh pemerintah.

Teknik pengumpulan data dalam penelitian ini adalah wawancara dandokumentasi. Wawancara yang digunakan adalah wawancara semi terstruktur. Wawancara jenis ini dipilih karena indikator penilaian buku telah ditetapkan sehingga rincian pertanyaan dibuat sesuai dengan indikator penilaian. Dokumentasi digunakan untuk mengumpulkan data yang bersumber dari dokumen, dalam hal ini buku teks pelajaran. Pengumpulan data dilakukan dengan menilai kesesuaian antara komponen kelayakan aspek kebahasaan dari buku teks Bahasa Indonesia sebagai objek penelitian untuk dianalisis kesesuaiannya dengan standar isi.

Instrumen penelitian kualitatif utamanya adalah peneliti itu sendiri. Di lain pihak, Standar Isi merupakan produk pemerintah yang tertera jelas dalam peraturanperaturan yang dibuat pemerintah. Standar Isi mencakup (mengatur) banyak hal, termasuk tentang penilaianaspekkebahasaan sebuah buku teks. Oleh sebab itu, peneliti menggunakan standar kriteria penilaian aspek kebahasaan buku teks dalam melakukan analisis hasil penelitian. Adapun kisi-kisi penilaian sebagai berikut.

Tabel 1. Kisi-kisi penilaianaspek kebahasaan buku

\begin{tabular}{|l|ll|}
\hline \multicolumn{1}{|c|}{ Aspek } & \multicolumn{1}{c|}{ Indikator } \\
\hline $\begin{array}{l}\text { A. Kesesuaian Dengan Tingkat } \\
\text { Perkembangan Peserta Didik }\end{array}$ & a) $\begin{array}{l}\text { Kesesuaian dengan tingkat perkembangan } \\
\text { intelektual peserta didik }\end{array}$ \\
\hline & b) Kesesuaian dengan tingkat perkembangan \\
B. Komunikatif & a) Keterbacaan pesan \\
\hline C. Keruntutan dan Kesatuan & b) Ketepatan bahasa \\
\hline & a) Keruntutan dan keterpaduan bab \\
\hline
\end{tabular}


Gagasan

b) Keruntutan dan keterpaduan paragraf

Sumber: Instrumen Penilaian Buku Teks Pelajaran Tahun 2014 (BSNP-indonesia.org $/ ? \mathrm{p}=1340)$

Teknik analisis data yang digunakan dalam penelitian ini adalah simak catat (content analysis).Menurut weber (Moleong, 2007: 163) simak catat merupakan metodologi peneliti yang memanfaatkan seperangkat prosedur untuk menarik kesimpulan yang shahih dari sebuah buku atau dokumen, desain simak catat menurutKrippendorff (1993: 69) adalah (1) Pengadaan Data; (2) Pengurangan (reduksi) data; (3)Inferensi; (4) Analisis.Analisis berhubungan dengan proses identifikasi dan penampilan pola-pola yang penting, yang merupakan deskripsi hasilhasil proses simak catat. Dalam proses simak catat analisis dilakukan setelah melakukan inferensi.

\section{Hasil dan Pembahasan}

Penilaian kesesuaian kebahasaan pada BSE Bahasa Indonesia SMPN kelas VII terbagi dalam tiga aspek, yaitu: (1) kesesuaian dengan tingkat perkembangan peserta didik; (2) komunikatif; dan (3) keruntutan dan kesatuan gagasan. Data hasil wawancara yang telah didapat dari narasumber dipaparkan dan dibagi dalam ketiga aspek tersebut.

\section{Kesesuaian Dengan Tingkat Perkembangan Peserta Didik}

Aspek kesesuaian dengan tingkat perkembangan peserta didik dalam penilaian kebahasaan buku teks terbagi menjadi 2 indikator. Pertama adalah kesesuaian dengan tingkat perkembangan intelektual peserta didik. Kedua ialah kesesuaian dengan tingkat perkembangan sosial emosional peserta didik

a) Kesesuaian dengan tingkat perkembangan intelektual peserta didik

Berdasarkan data penelitian pada aspek Kesesuaian dengan tingkat perkembangan peserta didik terlihat banyak kata-kata dalam buku yang tidak dipahami oleh peserta didik. Tabel 2 menyajikan kata-kata yang dipahami dan tidak dipahami oleh narasumber. Kata yang dipahami akan diberikan tanda cetang $(\sqrt{ })$, sedangkan untuk kata yang tidak dipahami akan diberikan tanda silang $(\mathrm{x})$

Tabel 2. Kata-kata yang tidak dipahami peserta didik

\begin{tabular}{|c|c|c|c|c|c|}
\hline No & Data & Kata & FNR & $\mathrm{BOH}$ & IAS \\
\hline 1 & 1 & Gairah & $\mathrm{X}$ & $\mathrm{X}$ & $\mathrm{X}$ \\
\hline 2 & 2 & Subjektif & $\mathrm{X}$ & $\mathrm{X}$ & $\mathrm{X}$ \\
\hline 3 & 2 & Memerinci & $\sqrt{ }$ & $\mathrm{X}$ & $\mathrm{X}$ \\
\hline 4 & 2 & Sudut pandang & $\sqrt{ }$ & $\sqrt{ }$ & $X$ \\
\hline 5 & 3 & Personal & $X$ & $X$ & $\mathrm{X}$ \\
\hline 6 & 3 & Konteks & $\mathrm{X}$ & $\mathrm{X}$ & $\mathrm{X}$ \\
\hline 7 & 4 & Perincian & $\sqrt{ }$ & $\mathrm{X}$ & $\mathrm{X}$ \\
\hline 8 & 5 & Secara konkret & $\sqrt{ }$ & $\bar{X}$ & $\bar{X}$ \\
\hline 9 & 6 & Kategori & $\sqrt{ }$ & $\sqrt{ }$ & $\mathrm{X}$ \\
\hline 10 & 6 & Berdiri sendiri & $\sqrt{ }$ & $\mathrm{X}$ & $\sqrt{ }$ \\
\hline 11 & 7 & Majas & $\mathrm{X}$ & $X$ & $\mathrm{X}$ \\
\hline 12 & 7 & Asosiasi & $\mathrm{X}$ & $\mathrm{X}$ & $\mathrm{X}$ \\
\hline 13 & 7 & Personifikasi & $\mathrm{X}$ & $\mathrm{X}$ & $\mathrm{X}$ \\
\hline 14 & 8 & Telaah & $\mathrm{X}$ & $\bar{X}$ & $\mathrm{X}$ \\
\hline 15 & 10 & Supranatural & $\bar{X}$ & $\mathrm{X}$ & $\sqrt{ }$ \\
\hline 16 & 10 & Supernatural & $\mathrm{X}$ & $X$ & $\mathrm{X}$ \\
\hline 17 & 10 & Futuristik & $\mathrm{X}$ & $\mathrm{X}$ & $\mathrm{X}$ \\
\hline 18 & 11 & Kata konkret & $\mathrm{X}$ & $\mathrm{X}$ & $\mathrm{X}$ \\
\hline 19 & 12 & Objektif & $X$ & $X$ & $X$ \\
\hline 20 & 12 & Sistematis & $\mathrm{X}$ & $\mathrm{X}$ & $\mathrm{X}$ \\
\hline 21 & 12 & Definisi & $\mathrm{X}$ & $\mathrm{X}$ & $\mathrm{X}$ \\
\hline 22 & 12 & Klasifikasi & $\mathrm{X}$ & $X$ & $\mathrm{X}$ \\
\hline 23 & 12 & Jabaran & $\bar{X}$ & $\mathrm{X}$ & $\bar{X}$ \\
\hline 24 & 13 & Investigasi & $\mathrm{X}$ & $\mathrm{X}$ & $\mathrm{X}$ \\
\hline 25 & 13 & Sistematis & $\mathrm{X}$ & $\mathrm{X}$ & $\mathrm{X}$ \\
\hline 26 & 13 & Observasi & $\sqrt{ }$ & $\mathrm{X}$ & $\mathrm{X}$ \\
\hline
\end{tabular}




\begin{tabular}{|c|c|l|c|c|c|}
\hline 27 & 13 & Analisis & $\sqrt{ }$ & $X$ & $X$ \\
\hline 28 & 13 & Riset & $\sqrt{ }$ & $X$ & $X$ \\
\hline 29 & 14 & Memetekan & $X$ & $X$ & $X$ \\
\hline 30 & 15 & Memetakan paragraf & $X$ & $X$ & $X$ \\
\hline
\end{tabular}

Berdasarkan data di tabel 2 terlihat bahwa dari 30 kata yang sulit dipahami (berdasarkan hasil wawancara), hasilnya adalah: narasumber FNR memahami 9 kata $(30 \%)$; narasumber $\mathrm{BOH}$ memahami 2 kata (6,6\%); dan narasumber IAS memahami 2 kata $(6,6 \%)$. 30 kata yang terdapat dari 14 data yang disajikan tersebut dimasukkan ke dalam kategori indikator kesesuaian dengan tingkat intelektual perkembangan peserta didik. Hal ini dilakukan karena kemampuan menerjemahkan 30 kata tersebut erat kaitannya dengan kecerdasan dan pengetahuan peserta didik. Pengetahuan peserta didik didapat dari dalam diri peserta didik (faktor internal), dan faktor yang terdiri dari luar (faktor eksternal) (Syah, 2004: 132). Kecerdasan dan pengetahuan yang dimiliki oleh siswa kelas VII SMPN 1 Plaosan tidak mampu menerjemahkan hampir seluruh kata yang disajikan dalam BSE Bahasa Indonesia Kelas K-13 VII. Hasilnya adalah siswa mudah bingung dalam menerjemahkan wacana tertentu dalam buku. Dampaknya sulit bagi siswa untuk belajar mandiri dari buku yang telah disediakan karena mereka membutuhkan "penerjemah" dalam memahami isi buku. Oleh sebab itu, peran guru menjadi sangat sentral dalam proses pembelajaran.

b) Kesesuaian dengan tingkat perkembangan sosial emosional peserta didik

Pada indikator perkembangan sosial emosional ini BSNP (2014: 1) menjelaskan bahwa bahasa yang digunakan harus sesuai dengan kematangan sosial emosional peserta didik dengan wacana, teks, gambar dan ilustrasi yang menggambarkan konsep-konsep mulai dari lingkungan terdekat (lokal) sampai dengan lingkungan global. Peneliti beranggapan bahwa kematangan sosial emosional yang dimaksud disini adalah bahasa di dalam buku harus mampu membuat peserta didik ingin tahu dan bekerjasama dengan teman. Berdasarkan pengamatan peneliti tidak ada bagian dalam buku yang melanggar dari indikator ini. Semua bagian dalam buku mengajak peserta didik untuk melakukan eksplorasi terhadap materi dan diperintahkan untuk melakukannya bersama-sama dalam kelompok.

\section{Komunikatif}

Terdapat dua indikator dalam aspek ini, yaitu keterbacaan pesan dan ketepatan bahasa.

\section{1) Keterbacaan bahasa}

Keterbacaan pesan erat kaitannya dengan penggunaan bahasa yang menarik, jelas, pemilihan katanya sesuai dengan yang diwakili, tidak menimbulkan makna ganda, dan lazim dalam penggunaan bahasa Indonesia. Kebingungan yang dialami oleh narasumber pada indikator ini karena penggunaan kata yang membingungkan. Kata-kata yang terdapat dalam data-data di indikator ini tidak membuat narasumber bingung. Akan tetapi, kebingungan terjadi pada saat kata-kata tersebut dirangkaikan menjadi kalimat utuh. Sebagai contoh:

\section{Data 1}

Teks deskripsi menggunakan kosakata secara segar dengan variasi kata yang luas.

Semua kata pembangun kalimat dalam data 1 dipahami oleh semua narasumber. Akan tetapi, ketika narasumber ditanyakan makna dari kalimat dalam data 1 maka semua merasa bingung. Narasumber FNR dan BOH mulai tidak paham saat membaca di bagian 'secara segar'. Sedangkan, narasumber IAS memaknai kata 'secara segar' sebagai seperti haus minum air dingin. Jelas sekali narasumber IAS juga tidak memahami makna kalimat secara keseluruhan. Kata segar dalam KBBI (2008: 1139) berarti berasa nyaman dan ringan; merasa nyaman; nyaman dan sehat; baik tumbuhnya; masih baru; tidak layu. Apabila dikaitkan antara kata 'segar' dalam data 18 dan dalam KBBI, maka kata 'segar' tersebut dapat dimaknai sebagai jelas, nyaman dibaca, tidak membingungkan.

2) Ketepatan bahasa 
Penilaian ketepatan bahasa dalam buku mengacu pada kata atau kalimat yang ada sesuai dengan EYD dan penggunaan istilah yang tepat makna dan konsisten. Sebagai contoh:

Data 2

Cerita mengungkapkan hal-hal supranatural/ kemisteriusan, keghaiban yang tidak ditemui dalam dunia nyata. Cerita fantasi adalah cerita fiksi bergenre fantasi (dunia imajinatif yang diciptakan penulis). Pada cerita fantasi hal yang tidak mungkin dijadikan biasa. Tokoh dan latar diciptakan penulis tidak ada di dunia nyata atau modifikasi dunia nyata. Tema fantasi adalah majic, supernatural atau futuristik.

Dalam data 2 terdapat dua kata yang mirip secara bentuk yaitu 'supranatural' dan 'supernatural'. Dalam KBBI $(2008,1250)$ supernatural berarti ajaib (tidak dapat diterangkan dengan akal sehat); gaib. Sedangkan kata supranatural tidak ditemukan dalam kamus KBBI. Dalam kamus bahasa Inggris Oxford (1987),yang ditulis oleh Hornby, tidak ditemukan kata supranatural, tetapi ditemukan kata 'supra' dan 'natural'. Kata 'supra' dalam kamus Oxford $(1987,869)$ berarti above (di atas). Sedangkan 'natural' dalam kamus Oxford $(1987,562)$ berarti by nature (alami). Dengan demikian jika menggunakan kamus Oxford kata supernatural berarti 'di atas alami' atau 'tidak alami'. Dengan analisis ini, kata 'supernatural' dan 'supranatural' memiliki kesamaan makna. Akan tetapi, inkonsistensi penulisan membuat timbulnya kebingungan pada narasumber FNR atau pembaca buku. Narasumber FNR dan IAS menyatakan bahwa kata 'supernatural' dan 'supranatural' memiliki perbedaan makna, sedangkan narasumber $\mathrm{BOH}$ menjawab tidak tahu.

\section{Keruntutan dan Kesatuan Gagasan}

Penilaian aspek keruntutan dan kesatuan gagasan terbagi menjadi dua indikator, yaitu (1) keruntutan dan keterpaduan bab; dan (2) keruntutan dan keterpaduan paragraf. Yang dimaksud dengan keruntutan dan keterpaduan bab dalam buku adalah pesan yang disampaikan melalui wacana, teks, gambar, ilustrasi antara satu bab dengan bab lain yang berdekatan dan antarsubbab dalam bab mencerminkan hubungan logis (BSNP, 2014: 1). Di lain pihak, penilaian keruntutan dan keterpaduan paragraf dilihat dari penyampaian pesan melalui wacana, teks, gambar, ilustrasi antarparagraf yang berdekatan dan antarkalimat dalam paragraf mencerminkan hubungan logis (BSNP, 2014: 2).

1) Keruntutan dan keterpaduan bab

Data penelitian menemukan timbulnya permasalahan di indikator ini, yaitu adanya tidak runtut antar subbab.

\section{Data 3}

\subsection{Mendaftar Kalimat Bermajas}

Data 3 merupakan judul subbab di dalam bab Teks Deskripsi. Data 3 adalah subbab tugas yang harus dikerjakan siswa. Tugas tersebut adalah mencari kalimat bermajas. Logika sebuah tugas adalah diberi penjelasan terlebih dahulu sebelum tugas tersebut diberikan. Akan tetapi, pada data 3 tidak ada penjelasan sebelumnya berkaitan dengan materi majas. Materi pelajaran sebelum data 3 adalah tentang penggunaan kata depan di- dan huruf kapital, tidak menyinggung tentang majas.

Peneliti berpikir majas sudah dipelajari oleh narasumber di jenjang sebelumnya, yaitu sekolah dasar. Akan tetapi, data dari hasil wawancara dengan narasumber menyatakan bahwa semuanya belum pernah belajar tentang majas sebelumnya. Materi tentang majas boleh saja untuk diberikan di tingkat SMP Kelas VII, tetapi yang terlihat dari data 30 adalah siswa diberikan tugas bukan penjelasan. Hal ini membuat buku tidak bisa dipelajari secara mandiri. Peran guru menjadi sangat diperlukan.

2) Keruntutan dan keterpaduan paragraf

Menurut BSNP (2014: 3) keruntutan dan keterpaduan paragraf diukur dari hubungan logis yang terjadi antarparagraf dan antar kalimat yang berdekatan. salah satu data penelitian yang berkaitan dengan indikator ini adalah data 4 .

LinguistaVol. 1, No. 2, Desember 2017: 79-86 


\section{Data 4}

Kata umum adalah kata yang luas ruang lingkupnya dan dapat mencakup banyak hlm.Kata - kata yang termasuk dalam kata umum disebut dengan hipernim. Kata khusus adalah kata yang ruang lingkup dan cakupan maknanya lebih sempit. Kata - kata yang termasuk dalam kata umum disebut dengan hipernim. Kata umum dan kata khusus sebenarnya sinonim tetapi dengan makna yang lebih khusus.

Pada data 4 terjadi pengulangan kalimat 'Kata-kata yang termasuk dalam kata umum disebut dengan hipernim'. Pengulangan kalimat tersebut tidak diperlukan. Semua narasumber yang diwawancarai mengatakan bahwa kalimat tersebut diulang dan tidak mengetahui maksud dari pengulangan tersebut. Berdasarkan pengamatan peneliti terjadi kesalahan penjelasan. Pada bagian awal di data membahas tentang 'kata umum'. Kemudian, diteruskan dengan penjelasan tentang kata yang termasuk 'kata umum'. Penjelasan selanjutnya di data adalah tentang 'kata khusus'. Kemudian, diikuti dengan penjelasan tentang kata yang termasuk 'kata umum'. Seharusnya setelah penjelasan tentang 'kata khusus' diikuti juga dengan penjelasan yang berkaitan dengan 'kata khusus'. Disini terjadi hubungan yang tidak logis antarkalimat.

\section{Kesimpulan}

Terdapat 3 aspek kebahasaan yang dinilai dari sebuah buku teks, yaitu (1) aspek kesesesuaian dengan tingkat perkembangan peserta didik; (2) komunikatif; dan (3) keruntutan dan kepaduan paragraf. Aspek kesesuaian dengan tingkat perkembangan peserta didik terbagi menjadi dua indikator, yaitu (1) perkembangan intelektual peserta didik; dan (2) perkembangan sosial emosional peserta didik. Pada indikator tingkat perkembangan intelektual peserta didik hasil penelitian menunjukkan terdapat 30 kata yang tidak sesuai dengan perkembangan intelektual peserta didik. Pada indikator tingkat perkembangan sosial emosional peserta didik, peneliti tidak menemukan bagian di dalam buku yang bermasalah berkaitan dengan indikator ini. Dengan demikian, pada aspek kesesuaian dengan tingkat perkembangan peserta didik dalam indikator kesesuaian dengan tingkat perkembangan sosial emosional peserta didik hasil penelitian menyatakan terdapat kesesuaian antara buku sekolah elektronik Bahasa Indonesia Kelas VII dengan standar isi.

Aspek komunikatif dalam penilaian kebahasaan buku teks dibagi menjadi 2 indikator, yaitu (1) keterbacaan pesan; dan (2) ketepatan bahasa. Pada indikator keterbacaan pesan hasil penelitian menemukan 4 data yang berkaitan. Pada indikator ketepatan bahasa hasil penelitian menemukan 10 data yang berkaitan. Permasalahan yang terdapat dari 10 data tersebut adalah kesalahan tanda baca dan inkonsistensi. Dengan demikian, pada aspek komunikatif terdapat ketidaksesuaian antara buku sekolah elektronik Bahasa Indonesia Kelas VII dengan standar isi.

Aspek keruntutan dan kesatuan gagasan terbagi menjadi 2 indikator, yaitu (1) keruntutan dan keterpaduan subbab; dan (2) keruntutan dan keterpaduan paragraf. Pada indikator keruntutan dan keterpaduan subbab hasil penelitian menemukan 1 data yang berkaitan. Pada indikator keruntutan dan keterpaduan paragraf, hasil penelitian menemukan 4 data yang bermasalah. Dengan demikian, pada aspek keruntutan dan kesatuan gagasan terdapat ketidaksesuaian antara buku sekolah elektronik Bahasa Indonesia Kelas VII dengan standar isi.

\section{Daftar Pustaka}


BSNP. (2006). Standar Isi Untuk Satuan Pendidikan Dasar dan Menengah. Jakarta: Badan Standar Nasional Pendidikan

BSNP. (2014). Instrumen Penilaian Buku Teks Pelajaran Tahun 2014. BSNPindonesia.org /? $p=1340$ (diakses pada tanggal 17 Juni 2017, pukul 11:00)

Depdiknas. (2008). Panduan Pengembangan Bahan Ajar. Jakarta: Depdiknas

Depdiknas. (2008). Kamus Besar Bahasa Indonesia. Jakarta: Pusat Bahasa Departemen Pendidikan Nasional

Hornby, A.S. (1987). Oxford Advanced Learners Dictionary of Current English. United Kingdom: Oxford University Press

Krippendorff, K. (1993). Analisis Isi Pengantar Teori dan Metodologi. Jakarta: Raja Grafindo Persada

Moleong, L. J. (2007). Metodologi Penelitian Kualitatif. Bandung: Remaja Rosdakarya

Syah, M. (2004). Psikologi Pendidikan. Bandung: Remaja Rosda Karya

Sugiantomas, A., \& Wigunawan, K. (2015). ANALISIS BUKU TEKS BAHASA INDONESIA KELAS XI SMA SEKABUPATEN KUNINGAN DALAM MENJABARKAN SK/KD DILIHAT DARI KEILMUAN KEBAHASAAN DAN KESASTRAAN INDONESIA. Jurnal Fon, 3(2).

Undang-undang No. 20 tahun 2003 Tentang Sistem Pendidikan Nasional 